\title{
ANATOMIA VEGETATIVA DE BROMELIA ANTIACANTHA BERTOL. (BROMELIACEAE, BROMELIOIDEAE) ${ }^{1}$
}

\author{
GRETAALINEDETTKE ${ }^{2}$ MARIAAUXILIADORAMILANEZE-GUTIERRE ${ }^{3}$
}

\section{RESUMO}

Este estudo objetivou a análise anatômica dos órgãos vegetativos de Bromelia antiacantha Bertol. As folhas desta espécie são hipoestomáticas e cobertas por escamas, as quais exibem dimorfismo, mais abundantes na face abaxial e na região basal. As demais células epidérmicas são lignificadas, contendo corpúsculos silicosos. O mesofilo mostra-se composto por hipoderme espessa junto às faces adaxial e abaxial, parênquima aqüífero desenvolvido, parênquima clorofiliano e colunas de aerênquima (células braciformes) entre os feixes vasculares, sempre colaterais. $\mathrm{O}$ caule apresenta parênquima homogêneo, com cavidades mucilaginosas e idioblastos cristalíferos. O rizoma está composto por córtex espesso, com grãos de amido, e uma porção mais interna, onde se concentram os feixes vasculares. O sistema radical desta espécie é amplo e fasciculado. O velame diferencia-se em epivelame, formando pêlos nas raízes jovens, enquanto que no córtex há expressivos canais de ar e na endoderme observam-se espessamentos em "U". No cilindro central há pólos de xilema e floema intercalados, estando a porção central altamente lignificada.

Palavras-chave: Bromelia antiacantha, Bromeliaceae, anatomia vegetal, órgãos vegetativos.

\section{ABSTRACT}

[Vegetative anatomy of Bromelia antiacantha Bertol. (Bromeliaceae, Bromelioideae)].

This study aimed to analyze the anatomy of the vegetative organs of Bromelia antiacantha Bertol. The leaves are hypostomatic and covered by scales, which exhibit dimorphism, being more abundant in the abaxial leaf side and in the basal area. The other epidermal cells are lignified, containing silica bodies. The mesophyll is composed by a thick hypoderm in the adaxial and abaxial sides, with well developed aqüiferous parenchyma, chlorophyllous tissue and aerenchyma columns (braciform cells) among the collateral vascular bunches. The stem shows homogeneous parenchyma, with mucilaginous cavities and crystalliferous idioblasts. The rhizome is composed by a thick cortex with starch grains and a more internal portion, where occurs the vascular bundles. The radical system is wide and fasciculate. The velame differs in epivelame, forming hairs in the young roots, while in the cortex there are expressive air canals and " $U$ " form thickenings in the endoderm. In the central cylinder there are xylem poles and inserted phloem, being highly lignified in the central portion.

Key words: Bromelia antiacantha, Bromeliaceae, plant anatomy, vegetative organs.

1 Recebido em 30/03/2008 e aceito para publicação em 10/05/2008.

2 Bióloga, bolsista CAPES, mestranda do Programa de Pós-Graduação em Botânica, Universidade Federal do Rio Grande do Sul. CEP 91501-970, Porto Alegre (RS). gretadet@yahoo.com.br

3 Bióloga, Dra., Professora Adjunta do Departamento de Biologia, Universidade Estadual de Maringá, CEP 87020-900, Maringá (PR). milaneze@uem.br 


\section{INTRODUÇÃO}

A família Bromeliaceae é predominantemente neotropical, incluindo cerca de 60 gêneros e 3000 espécies, distribuídas em três subfamílias bem definidas: Pitcairnoideae, Tillandsioideae e Bromelioideae (Smith \& Downs, 1979). No Brasil, ocorrem cerca de 40 gêneros e 1200 espécies amplamente distribuídas (Souza \& Lorenzi, 2005), principalmente na Mata Atlântica (Reitz, 1983).

O gênero Bromelia conta com aproximadamente 47 espécies (Smith \& Downs, 1979), desde o norte do México até o Uruguai e norte da Argentina (Reitz, 1983).

Bromelia antiacantha ${ }^{1}$ Bertol., conhecida popularmente como caraguatá ou gravatá, ocorre naturalmente do Espírito Santo ao Rio Grande do Sul (Reitz, 1983). Trata-se de uma espécie terrestre de grande porte, podendo atingir 2 $3 \mathrm{~m}$ de altura (Figura 1). Possui caule curto, grosso, emitindo rizomas também grossos e recobertos por folhas de até um metro de comprimento, responsáveis pela ampla propagação vegetativa da espécie. Do caule e rizoma surgem raízes adventícias, pouco profundas e bastante ramificadas. As folhas, muito numerosas, encontram-se dispostas em roseta bastante densa, sem formar cisterna. A lâmina foliar é rijamente ereta, canaliculada, coberta de escamas esbranquiçadas e com margens espinhosas (Reitz, 1983).

Do centro das folhas de $B$. antiacantha emerge a inflorescência, composta por 150-350 flores ornitófilas e meliófilas. Durante o período de floração (dezembro-fevereiro), as folhas centrais e brácteas assumem uma coloração vermelha intensa (Canela \& Sazima, 2005). Os frutos são bagas ovaladas de cor amarela, odor agradável, polpa comestível e com muitas sementes; estas se revelam fotoblásticas neutras

Do grego anti (contra) e ácantha (espinho), como referência à disposição dos espinhos, que, na parte basal da lâmina foliar, estão dirigidos para baixo, ao contrário da parte superior. e com alta taxa de germinação, mesmo após longo período de estocagem (Dettke \& MilanezeGutierre, 2004).

Bromelia antiacantha é utilizada como cerca viva, na confecção de cordas e tapetes, e seus frutos e folhas são usados na medicina caseira. Segundo Andrighetti-Fröhner et al. (2005), os frutos são utilizados como emoliente e expectorante em infecções respiratórias, bem como para asma e bronquite.

De acordo com Reitz (1983), a espécie desenvolve-se, principalmente, nos solos muito úmidos de florestas, na restinga e vegetação secundária, formando sempre densos agrupamentos de forma descontínua, pelos diversos ambientes que ocupa. Segundo Cogliatti-Carvalho et al. (2001), a espécie é encontrada nas áreas de vegetação fechada pós-praia e em mata periodicamente inundada, o que sugere certa tolerância à alta salinidade.

No Paraná, a espécie é frequiente às margens da planície de inundação do Alto rio Paraná, permanecendo submersa em períodos curtos de cheia (alguns dias até dois meses), fato que indica tolerância a este tipo de estresse. Também está associada a ambientes bastante úmidos no Rio Grande do Sul (Meira, 1997).

Os estudos morfológicos, anatômicos e fisiológicos das Bromeliáceas têm revelado adaptações que tornam possível sua sobrevivência em ambientes estressados. No presente estudo, objetivou-se analisar a anatomia dos órgãos vegetativos de $B$. antiacantha, fornecendo subsídios para futuros estudos ecofisiológicos com a espécie.

\section{MATERIAIS E MÉTODOS}

O material estudado, proveniente de sementes coletadas na vegetação ripária do Alto rio Paraná (Porto Rico, PR), resulta de cultivo no Horto Didático de Plantas Medicinais "Prof Irenice Silva", da Universidade Estadual de Maringá (UEM), e encontra-se depositado no herbário da mesma universidade, sob o registro HUEM12158. 


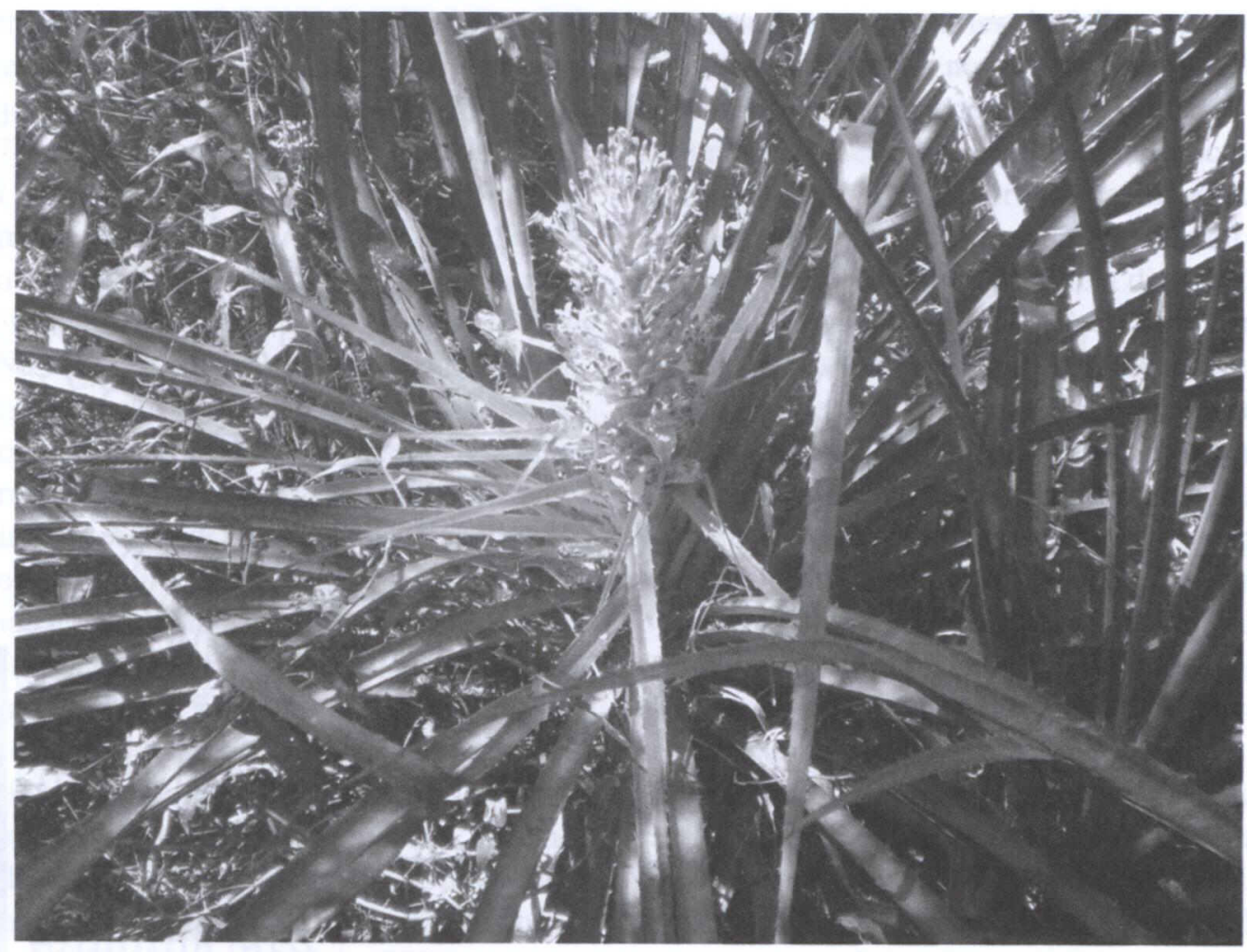

FIGURA 1 - Espécime em floração de Bromelia antiacantha Bertol.

Para a análise histológica foram preparadas seções anatômicas em diversos planos, à mão livre, com auxílio de lâmina de barbear, a partir de fragmentos de material vegetativo maduro, utilizando-se tecidos frescos. Em seguida, foram descoradas em hipoclorito de sódio $33 \%$, por cinco minutos, coradas com azul-de-astra e safranina (Kraus \& Arduin, 1997), e montadas em gelatina glicerinada, como lâminas semi-permanentes.

Para os testes microquímicos utilizou-se solução de lugol, para a identificação dos grãos de amido; cloral hidratado $60 \%$, em solução com ácido sulfúrico $25 \%$ em etanol absoluto, para revelar a presença de oxalato de cálcio; celulose e lignina, diferenciadas pelo cloreto de zinco iodado (Kraus \& Arduin, 1997); Sudan IV, para a cutina e demais substâncias lipídicas; fenol líquido, para a detecção de sílica; e cloreto férrico
10\%, para substâncias fenólicas (Johansen, 1940).

Os desenhos foram elaborados com o auxílio de câmara clara e as ilustrações obtidas com fotomicroscópio Olympus (modelo BX51) e programa Image Pro Express, projetando-se, nas mesmas condições ópticas, as escalas correspondentes.

\section{RESULTADOS E DISCUSSÃO}

As características anatômicas reveladas por Bromelia antiacantha corroboram, em geral, as informações apresentadas, por diversos autores, para espécies da família Bromeliaceae.

As folhas de $B$. antiacantha apresentam-se com ambas as faces foliares recobertas por escamas peltadas (Figuras 2a-c). As escamas estão inseridas em fileiras paralelas seguindo o eixo longitudinal da folha, em depressões da 

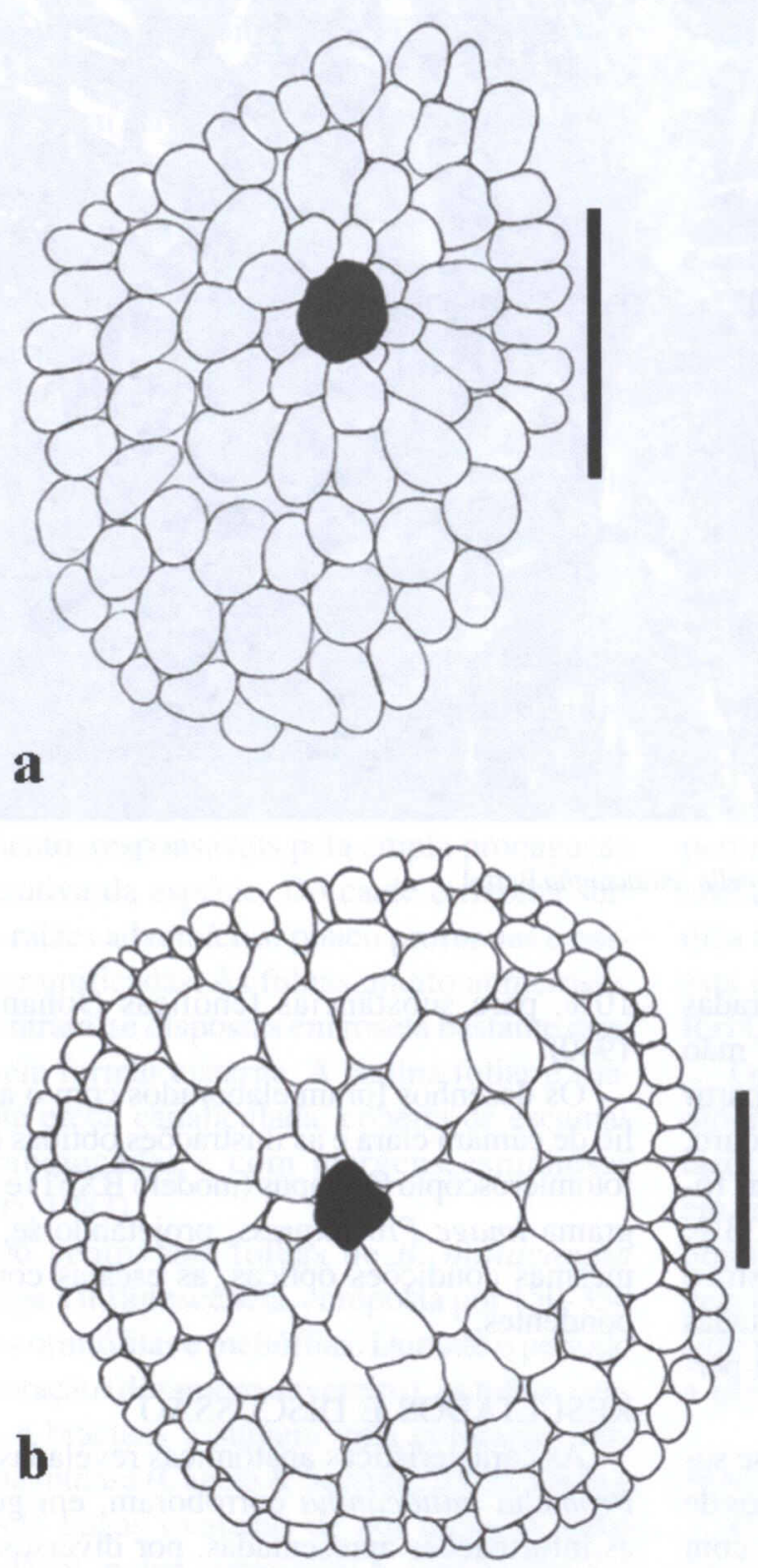

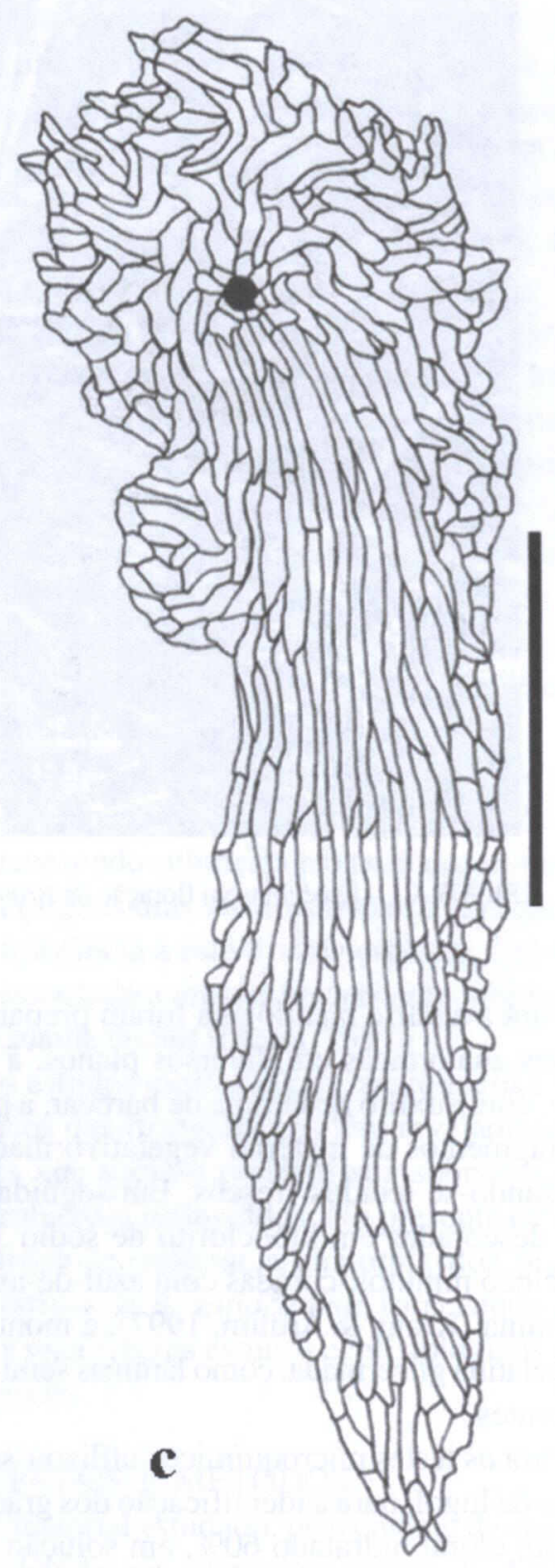

FIGURA 2 - Escamas peltadas da folha de Bromelia antiacantha Bertol. Face adaxial (a). Face abaxial (b). Região basal do limbo (c). Escala a,b $=100 \mu \mathrm{m} ; \mathrm{c}=500 \mu \mathrm{m}$. 
epiderme, como também observados por outros autores, tais como Souza et al. (2005), Proença \& Sajo (2004), Aoyama \& Sajo (2003) e Braga (1977), para outras espécies de Bromeliaceae. Estas escamas foliares apresentam diferenças de tamanho e morfologia, conforme a região do limbo analisada. Na face adaxial, são menores, menos abundantes e não se sobrepõem (Figura 2a). Na face abaxial, são maiores e mais abundantes, cobrindo os poros estomáticos e se sobrepondo (Figura 2b). Embora as escamas foliares de $B$. antiacantha estejam presentes nas duas superfícies, no presente trabalho observou-se maior abundância na superfície abaxial, à semelhança do que ocorre em espécies de Aechmea (Bromelioideae) estudadas por Souza et al. (2005). De acordo com Strehl (1983), estes caracteres são mais conservativos na superfície abaxial do que na adaxial, a qual está mais exposta às variações macroclimáticas. A região da folha que mostra maior quantidade de escamas é a região basal, como também ressaltado por Braga (1977) e Proença \& Sajo (2004).

As escamas possuem uma célula basal e o pedículo é formado por duas células alongadas e outras duas células aproximadamente cúbicas (Figura 3a), cujas paredes celulares possuem deposição de compostos lipídicos. O escudo é frequientemente assimétrico, sendo que as duas células centrais também possuem deposição de substâncias lipídicas em suas paredes. Em torno destas, estão 3-4 camadas de células com paredes celulósicas de formato ovalado, tenuemente ligadas entre si e dispostas concentricamente em torno das centrais (Figuras 2a-b).

$\mathrm{Na}$ região da base foliar, onde as folhas encontram-se firmemente imbricadas, há grande quantidade de escamas assimétricas, em ambas as faces foliares (Figura 2c). As células periféricas do escudo são alongadas e formam uma cauda, freqüentemente ultrapassando 1 milímetro de comprimento, sendo suberificadas as paredes de todas as suas células.

De acordo com Tomlinson (1969), as escamas da base em geral são maiores do que as escamas das outras partes da folha, como observado neste estudo; no entanto, Braga (1977) encontrou escamas menores na região basal, em algumas espécies analisadas. Segundo Scatena \& Segecin (2005), a presença de escudo assimétrico estaria relacionada ao aumento da captação de água e nutrientes nela dissolvidos, pelo aumento da superfície em contato com o fluído, o que seria importante para a espécie em estudo, já que suas folhas não formam cisterna.

As células epidérmicas de $B$. antiacantha são pequenas, quadrangulares ou retangulares, possuindo paredes sinuosas, altamente espessadas e lignificadas, com exceção da parede periclinal externa, que permanece fina e recoberta por uma fina cutícula (Figuras 3a-b). No interior das células epidérmicas comuns observa-se um corpúsculo esférico de sílica.

As células epidérmicas mostram as estruturas características de toda a família, segundo Tomlinson (1969), incluindo parede periclinal externa delgada, paredes anticlinais e periclinal interna espessas, lume pequeno e com um corpo silicoso esférico em seu interior, sendo as células da epiderme superior de estrutura semelhante às da epiderme inferior. Características da epiderme, como espessamento e presença/ausência de corpos silicosos, são freqüentemente utilizados como caracteres para a distinção de espécies de Bromeliaceae (Aoyama \& Sajo, 2003; Scatena \& Segecin, 2005).

Os corpos silicosos são encontrados nas células epidérmicas de todas as regiões do limbo foliar e, de acordo com Baumert (1907 apud Braga, 1977), sua presença atenuaria a incidência direta dos raios solares, por reflexão, evitando o aquecimento e a conseqüente perda de água dos tecidos.

Os estômatos encontram-se organizados em fileiras paralelas longitudinais, as células-guarda apresentam paredes espessadas e a cutícula se projeta formando cristas (Figura 3b), à semelhança do observado por Proença \& Sajo (2004) em espécies de Aechmea. As células subsidiárias encontram-se subjacentes às células-guarda, possuindo paredes finas (Figura 3b), 


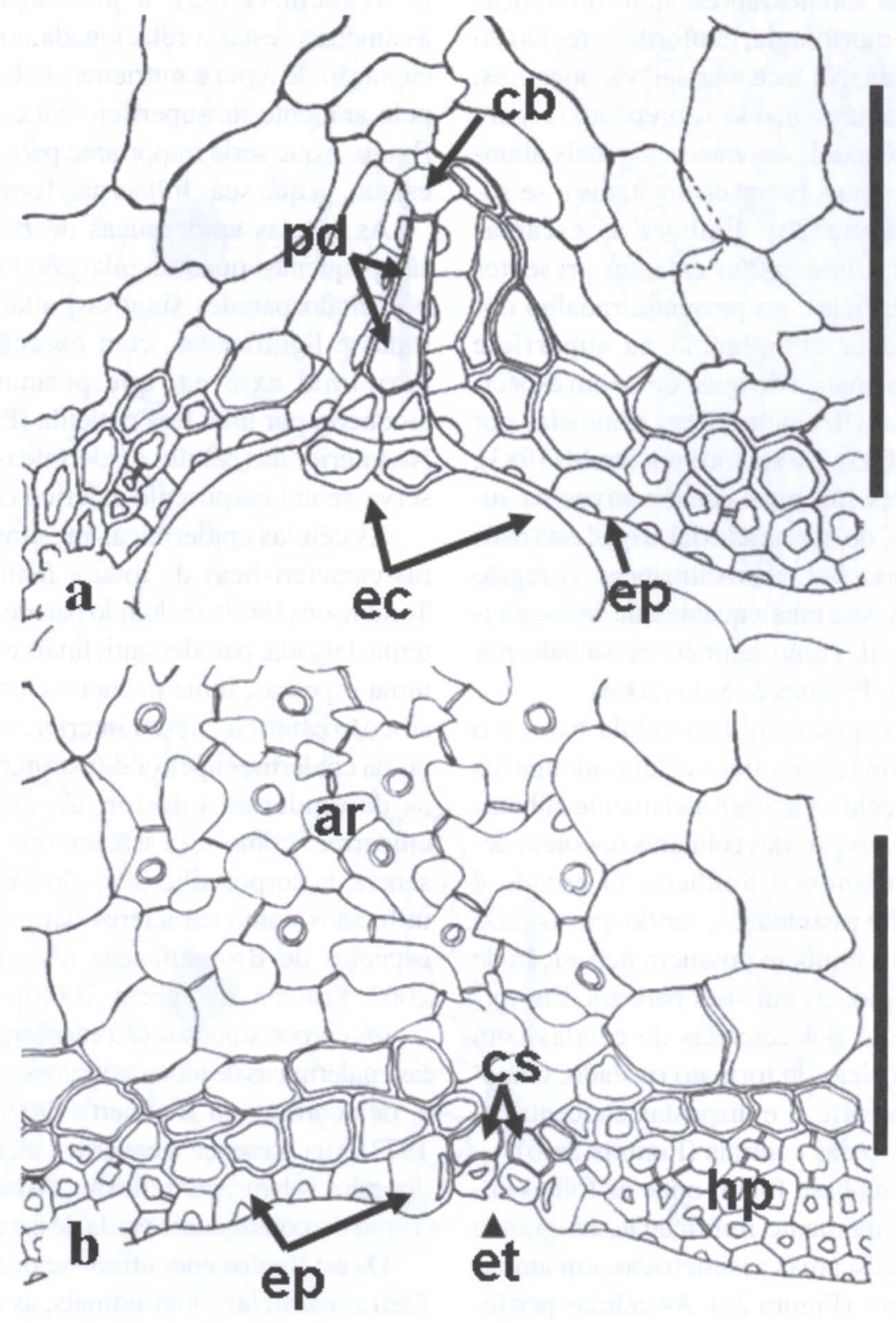

FIGURA 3 - Seções anatômicas transversais da face abaxial da folha de Bromelia antiacantha Bertol., mostrando a região de inserção de uma escama peltada (a) e um estômato (b). ar: aerênquima, cb: célula basal, cs: células subsidiárias, ec: escama peltada, ep: epiderme, et: estômato, hp: hipoderme, pd: pedículo. Escala a,b $=50 \mu \mathrm{m}$. 
impregnadas por substâncias lipídicas e sem corpos silicosos em seu interior. Os estômatos de $B$. antiacantha são recobertos pelo escudo das escamas, o que, de acordo com Tomlinson (1969), seria uma adaptação para evitar a perda de água para o ambiente. Também, na espécie em estudo, os estômatos ocorrem em depressões da epiderme, fato que Sousa et al. (2005) não consideram relacionado ao ambiente seco, visto que espécies de ambientes mais úmidos também apresentam a mesma característica, à semelhança da espécie em estudo.

Subjacente à epiderme adaxial encontra-se a hipoderme mecânica, composta por 2-3 estratos celulares (Figura 4a). Suas células têm lume bastante reduzido, pontuações evidentes e paredes lignificadas. $\mathrm{Na}$ face abaxial, esta hipoderme encontra-se melhor desenvolvida, constituída de 5-6 estratos celulares (Figura 4b). Também possui paredes celulares espessas e lignificadas, porém não forma uma camada contínua, como a hipoderme adaxial. É regularmente interrompida por depressões da epiderme, por ocasião da inserção das escamas e ocorrência de estômatos (Figuras 3b e 4a), dando à face abaxial o aspecto ondulado (Figura 4c). Na região do bordo foliar, a hipoderme é composta por mais camadas de células espessadas que se conectam com os espinhos.

Conforme observações de Tomlinson (1969), a hipoderme esclerificada em Bromeliaceae é contínua e uniforme na face adaxial e descontínua na face abaxial, onde se apresenta interrompida pelas câmaras subestomáticas; ainda segundo o autor, esse tecido apresenta células maiores nas camadas do bordo foliar que se projetam para o interior dos espinhos, estando de acordo com as observações de $B$. antiacantha.

Internamente à hipoderme adaxial, forma-se um parênquima aquífero, variável em sua constituição segundo a região da folha analisada. Este tecido é composto por células de paredes finas e sem cloroplastídeos (Figuras 4a e 4c). Na região basal da folha, ocupa até cerca da metade do mesofilo, sendo composta por 9-12 estratos celulares com células alongadas anticlinalmente e paredes levemente sinuosas na região mediana. Estas diminuem gradualmente de tamanho conforme distam do bordo foliar, onde ocorrem somente células isodiamétricas.

Na região mediana da folha, o parênquima aquiífero apresenta a mesma distribuição da região basal; este, porém, ocupa até cerca de um terço do mesofilo, composto por 3-6 estratos celulares. Na região apical, este tecido se reduz a 1-2 estratos celulares, geralmente com a ausência de células alongadas, ocupando menos de um quarto do mesofilo.

O parênquima clorofiliano ou clorênquima ocorre logo abaixo do parênquima aqüífero e nele estão imersos os feixes vasculares colaterais, formando uma série única no limbo foliar, onde se alternam feixes de maior calibre com feixes menores (Figuras $4 c-d$ ). Os feixes vasculares de maior calibre e os da região da borda são totalmente envoltos por fibras pericíclicas, ao passo que os menores apenas as possuem como calotas adjacentes aos pólos de floema e xilema. Ainda nesta porção, podem ser encontrados canais secretores de origem esquizógena (Figura 4d), semelhantes aos que eventualmente ocorrem na medula das raízes, e idioblastos com ráfides de oxalato de cálcio.

Na face abaxial, interiormente à hipoderme, encontra-se um parênquima aqüífero cujas células possuem cloroplastos, porém em menor quantidade do que o clorênquima propriamente dito (Figuras 4b-d). Nesta região ocorrem canais de ar preenchidos por células braciformes (oito braços), que se comunicam com as câmaras subestomáticas dos estômatos subjacentes (Figuras 4c-e), conforme também relatado por Tomlinson (1969), Braga (1977), Aoyama \& Sajo (2003), Proença \& Sajo (2004), Scatena \& Segecin (2005) e Souza et al. (2005), para outras espécies de Bromeliaceae.

O caule de $B$. antiacantha é muito reduzido em relação ao tamanho da planta, com cerca de $3 \mathrm{~cm}$ de altura e $4 \mathrm{~cm}$ de diâmetro. Seus entrenós, muito curtos, dificultam a observação da 


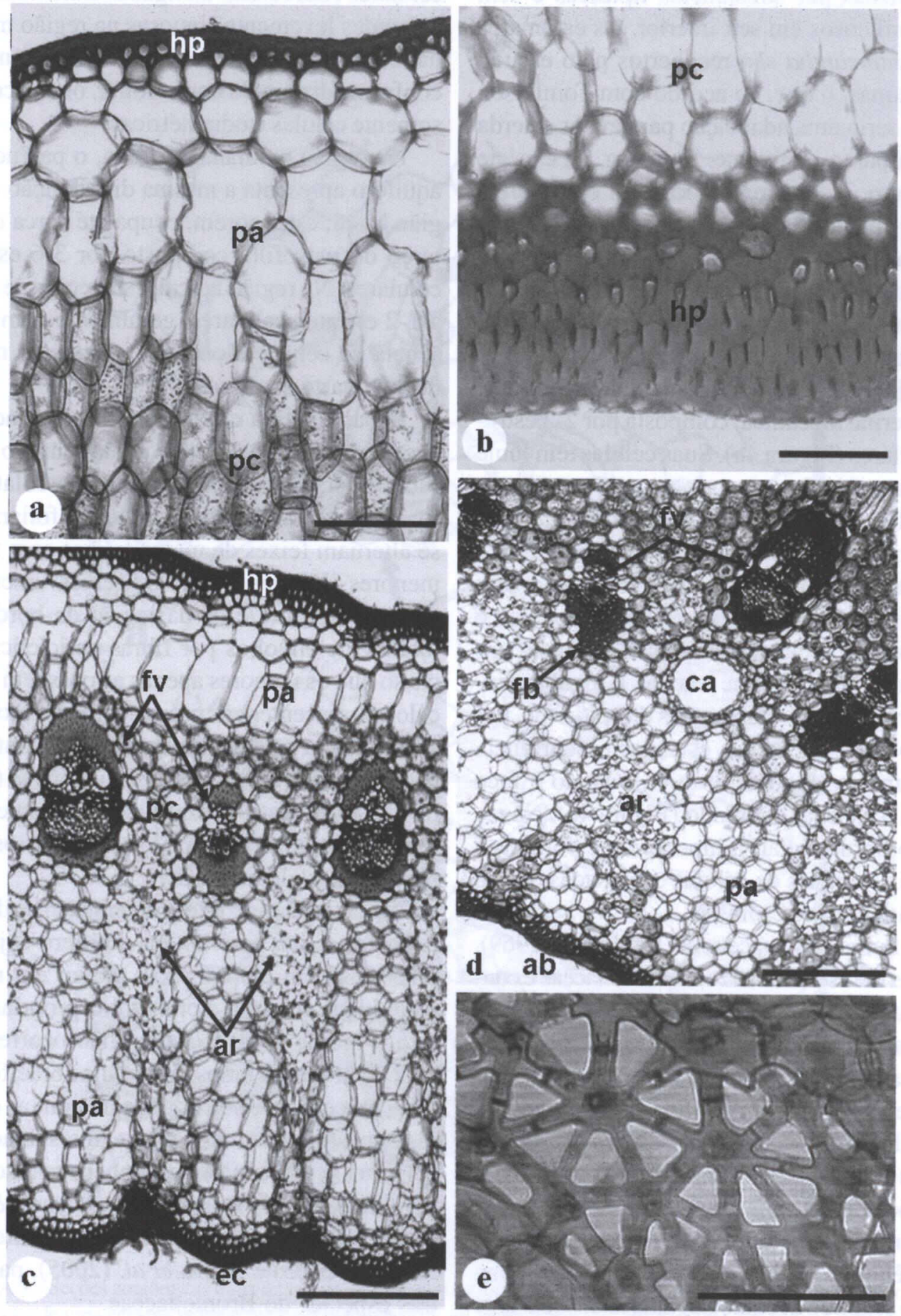

FIGURA 4 - Seções anatômicas transversais da folha de Bromelia antiacantha Bertol. Face adaxial (a). Face abaxial (b). Aspecto geral do limbo na região mediana $(\mathrm{c}, \mathrm{d})$. Detalhe das células braciformes do aerênquima (e). ab: face abaxial, ar: aerênquima, ca: canal secretor, ec: escamas peltadas, fb: calota de fibras, fv; feixes vasculares, hp: hipoderme, pa: parênquima aqüífero, pc, parênquima clorofiliano. Escala $a=100 \mu \mathrm{m} ; \mathrm{b}, \mathrm{e}=50 \mu \mathrm{m} ; \mathrm{c}, \mathrm{d}=250 \mu \mathrm{m}$. 
epiderme, que é uniestratificada e recoberta por fina cutícula. É formado por um parênquima homogêneo, de células aproximadamente isodiamétricas (Figura 5a). Por todo o caule estão dispersas cavidades mucilaginosas de origem lisígena, assim como feixes vasculares destituídos de fibras e idioblastos com ráfides.

$O$ rizoma de $B$. antiacantha, de formato arredondado a oval em seção transversal, está recoberto por escamas foliares secas. Atinge até cerca de um metro de comprimento antes de formar novas raízes adventícias e uma nova planta, sendo desprovido de ramificações.

As escamas foliares que cobrem o rizoma são constituídas por epiderme lignificada em ambas as faces, preenchidas por parênquima homogêneo, no qual são encontrados feixes vasculares colapsados e totalmente esclerificados (Figura 5b). Todas as regiões da escama encontram-se impregnadas por substâncias lipídicas.

O rizoma é recoberto por uma periderme pluriestratificada, com 7-9 estratos celulares de paredes bastante espessas, lignificadas e suberificadas, tendo o lume formato arredondado ou retangular, em seção transversal (Figuras $5 b-c)$. Nessas paredes celulares estão evidentes pontoações, freqüentemente ramificadas.

Em $B$. antiacantha, a presença de um rizoma com súber e coberto por escamas foliares, também com impregnação de substâncias lipídicas de todas as suas células, deve estar relacionado com a proteção mecânica e, principalmente, com a restrição de perda de água por este órgão, funcionando como um isolante térmico, conforme indicado por Segecin \& Scatena (2004).

Internamente à periderme, é possível distinguir três regiões (Figura $5 \mathrm{~b}$ e $5 \mathrm{~d}$ ). A região externa é composta por 20-30 camadas de parênquima homogêneo, com células de paredes celulósicas finas e poucos feixes vasculares colaterais dispostos aleatoriamente, eventualmente acompanhados por fibras em seus pólos. A região mediana compreende $10-15$ estratos de fibras e outras células esclerenquimáticas, com paredes espessas e lignificadas, formando um cilindro quase contínuo; nesta porção também estão presente feixes vasculares. Internamente distingue-se uma região de parênquima homogêneo com muitos feixes vasculares colaterais, dispersos aleatoriamente e envoltos por fibras pericíclicas (Figura 5d). Idioblastos com ráfides são pouco freqüentes neste órgão, estando dispersos aleatoriamente. Amido é encontrado como substância armazenada neste órgão, o que certamente garante a propagação vegetativa da espécie.

Bromelia antiacantha apresenta raízes intracorticais (internas) e raízes adventícias (externas). As raízes intracorticais originam-se de camadas de células meristemáticas do periciclo situadas entre o córtex e o cilindro central do caule e do rizoma, que, segundo Tomlinson (1969), garantem a sustentação de espécies de bromélias.

As raízes adventícias apresentam uma epiderme pluriestratificada, constituindo um velame (Figura 6a), cuja camada periférica encontra-se diferenciada em epivelame. As células do epivelame têm formato de longos pêlos unicelulares na região apical das raízes (Figura 6b). Na região mediana e basal das raízes adventícias, os pêlos freqüentemente se rompem. O velame é composto por 6-8 camadas celulares, apresentando estratificação em algumas regiões e impregnação de lipídeos em suas paredes.

$\mathrm{O}$ velame, primariamente reconhecido em raízes de orquídeas, foi relatado por Pita \& Menezes (2002) para espécies terrestres de Dyckia e de Encholirium, e por Segecin \& Scatena (2004) para espécies epífitas de Tillandsia. De acordo com Benzing (1990), este tecido tem a capacidade de se embeber com soluções que depositam-se sobre as raízes, disponibilizando-as para os tecidos internos, além de fornecer proteção mecânica. Esta estratégia seria importante para $B$. antiacantha, já que a 

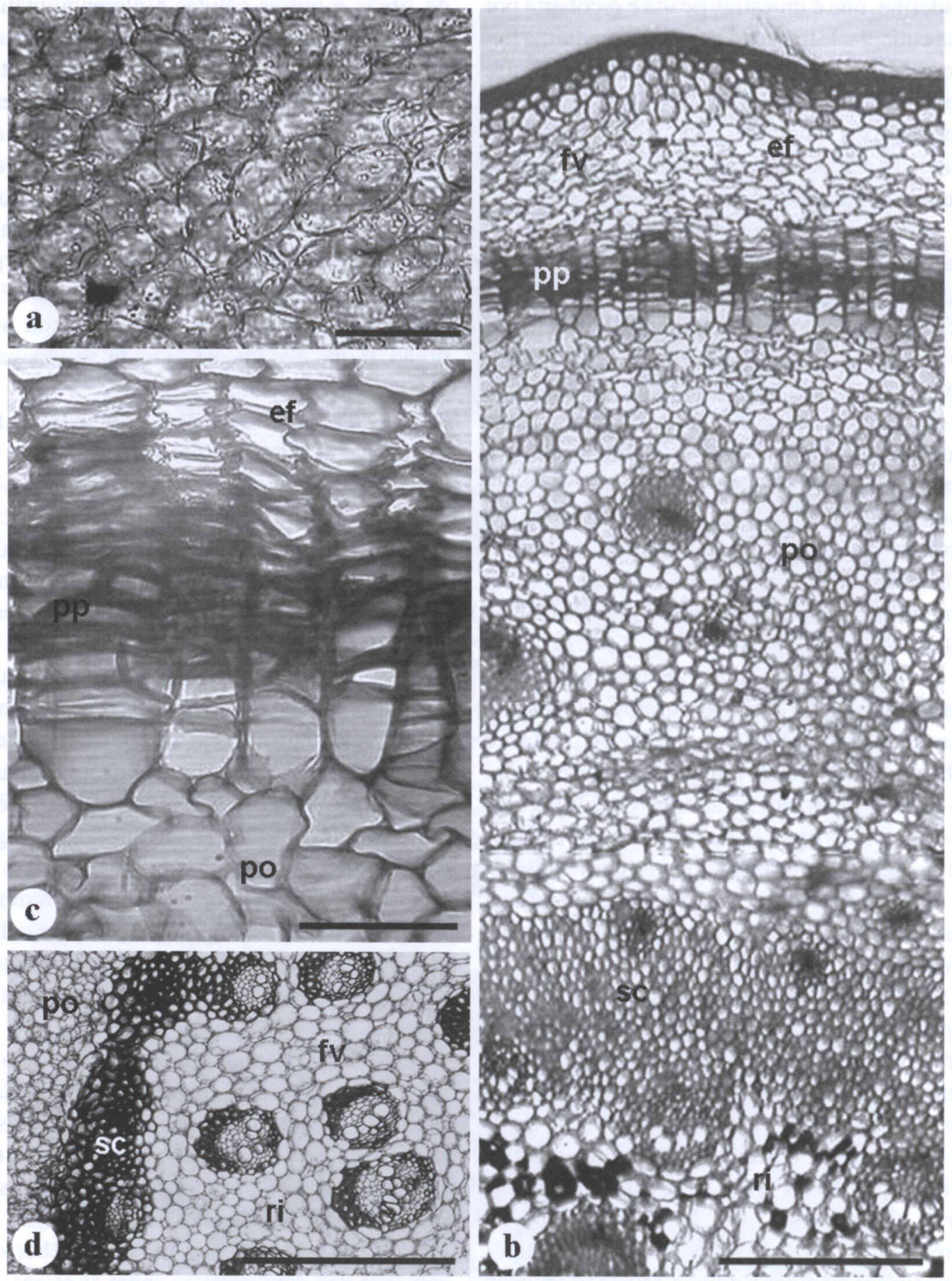

FIGURA 5 - Seções anatômicas transversais do caule e rizoma de Bromelia antiacantha Bertol. Aspecto do parênquima caulinar (a). Visão geral do rizoma (b). Detalhe da periderme pluriestratificada do rizoma (c). Detalhe das células esclerenquimáticas e feixes vasculares interiores do rizoma (d). ef: escama foliar, fv: feixe vascular, po, parênquima homogêneo, pp: epiderme pluriestratificada, ri: região interna, sc: esclerênquima. Escalas a,c $=100 \mu \mathrm{m} ; \mathrm{b}, \mathrm{d}=500 \mu \mathrm{m}$. 
espécie encontra-se freqüentemente sobre solos arenosos, que retém pouca umidade no período seco.

O córtex radical encontra-se dividido em córtex externo, córtex mediano e córtex interno (Figura 6a).

O córtex externo, subjacente ao velame, está constituído por células de formato aproximadamente hexagonal, com paredes secundárias e primárias espessas e lignificadas e lume bastante reduzido (Figura 6b). De acordo com Pita \& Menezes (2002), o córtex externo seria formado pela exoderme (ou hipoderme) e parte do córtex subjacente que adquire espessamento parietal nas porções mais diferenciadas das raízes, sendo estas regiões de difícil distinção. Segundo as autoras, isso pode ser comprovado pela presença somente da hipoderme nas regiões menos diferenciadas, confirmando as observações deste estudo. Em Bromelia antiacantha, a exoderme é formada por duas camadas celulares na região apical da raiz, sendo estas interrompidas por células de passagem.

As células do córtex externo reagem rapidamente à presença do oxigênio no ato do corte histológico, tornando-se escuras. Testes microquímicos indicaram a presença de compostos fenólicos em suas paredes celulares, sugerindo uma proteção adicional para as raízes, contra os organismos patogênicos do solo. Ainda nesta porção cortical encontram-se grandes idioblastos (Figuras 6a-b), freqüentemente contendo ráfides de oxalato de cálcio, com parede celular fina e formato aproximadamente isodiamétrico ou alongado.

Na região mediana do córtex, as células apresentam paredes celulósicas finas, de formato prismático a isodiamétrico, e diminutos espaços celulares. Frequientemente encontra-se amido nas células desta porção.

As células do córtex interno são maiores em relação às do córtex mediano, arredondadas e têm espaços intercelulares maiores. Intercalamse com grandes canais de ar, dispostos concentricamente em torno do cilindro central (Figura 6a) que, de acordo com Meyer (apud Pita \& Menezes, 2002), teriam a função de transportar água por capilaridade.

A endoderme de $B$. antiacantha é unisseriada, com estrias de Caspary evidentes próximo à região apical da raiz. Na região mediana e basal das raízes, as células da endoderme apresentam espessamento celulósico nas paredes anticlinais e periclinal interna, caracterizando $o$ espessamento em forma de "U" (Figura 6c). Internamente à endoderme encontra-se o periciclo, constituído por uma camada de células isodiamétricas, de paredes finas.

O cilindro vascular é poliarco, com aproximadamente 27-29 cordões de xilema alternando-se com cordões de floema, na região basal da raiz (Figura 6a e 6c). As células da medula são fibras de paredes espessadas, com deposição de lignina e lume reduzido; nas porções mais diferenciadas também se encontram substâncias fenólicas, integrando estas paredes. Apresentam-se bastante alongadas axialmente e com pontoações evidentes. Por vezes, na região central da medula encontra-se um canal secretor de origem esquizógena, que percorre toda a extensão da raiz.

Testes histoquímicos com Sudan IV indicaram a presença de substâncias lipídicas nas paredes primárias das células da endoderme e medula.

As raízes intracorticais apresentam a mesma constituição e organização de tecidos das raízes adventícias, diferindo destas pela ausência de velame e pêlos absorventes. Há somente uma epiderme bi ou trisseriada externamente ao córtex externo, que é mais desenvolvido. Pita \& Menezes (2002) também observaram tais características como diferenciais entre raízes adventícias e intracorticais de outras espécies de bromélias terrestres. Outra característica que a distingue da raiz adventícia é a presença de lignina nas paredes das células componentes da endoderme.

B. antiacantha apresenta diversas estruturas semelhantes a outras espécies de 

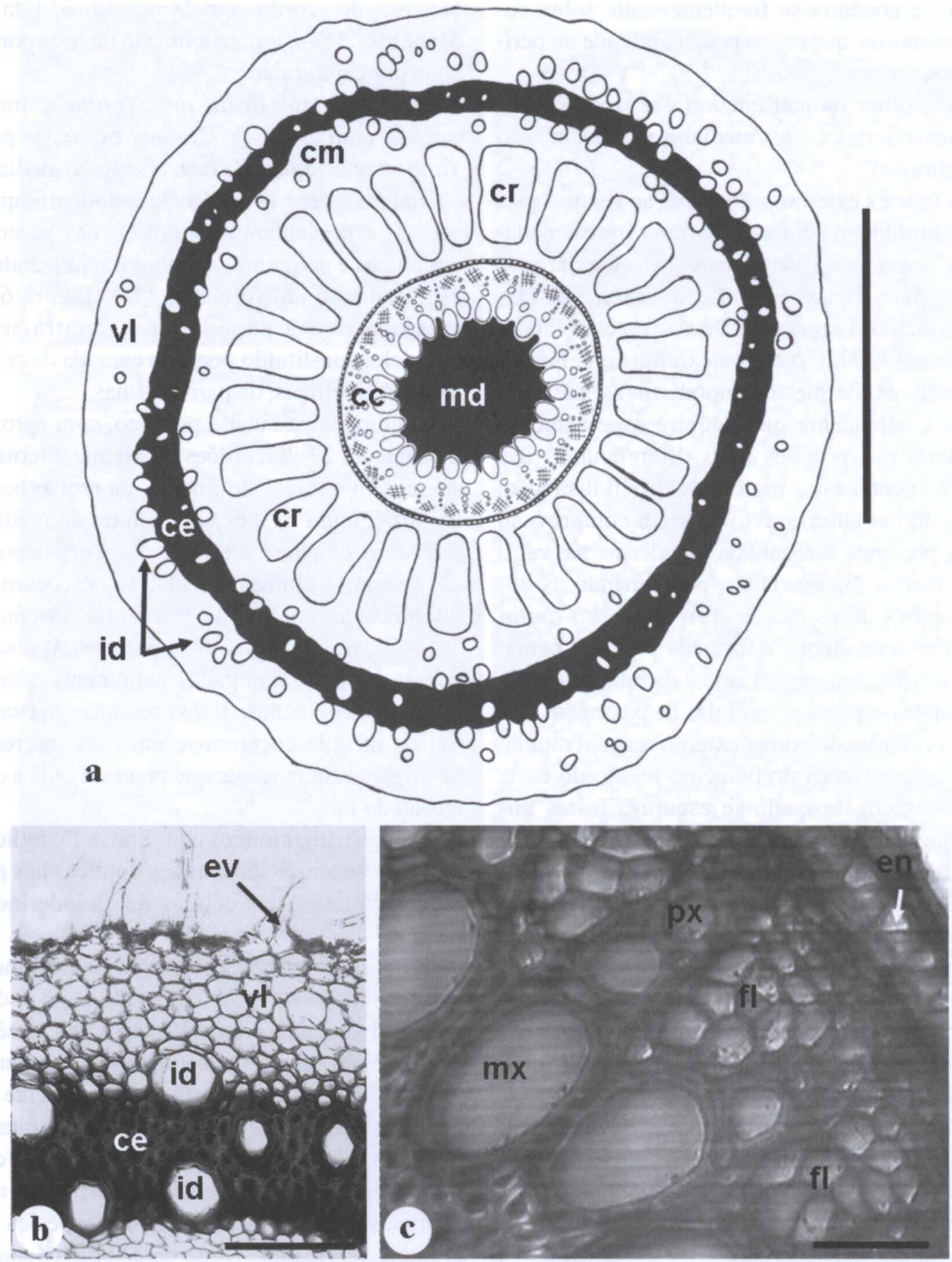

FIGURA 6 - Seções anatômicas transversais da raiz de Bromelia antiacantha Bertol. Esquema geral da distribuição de tecidos radicais (a). Detalhe da região superficial próximo ao ápice radical (b). Detalhe dos tecidos condutores do cilindro central (c). cc: cilindro central, ce: córtex externo, cm: córtex mediano, cr: canais de ar, em: endoderme, ev: epivelame, fl: floema, id: idioblastos, md: medula esclerificada, mx: metaxilema, px: protoxilema, vl: velame. Escala a $=1 \mathrm{~mm} ; \mathrm{b}=200 \mu \mathrm{m}$; $\mathrm{c}=50 \mu \mathrm{m}$. 
Bromeliaceae estudadas por diversos autores, tais como suculência foliar e presença de grande quantidade de tecidos mecânicos, salientando-se fibras e órgãos armazenadores de carboidratos, como o rizoma. Como caracteres úteis na diagnose desta espécie citam-se a presença de escamas peltadas distintas, conforme a região foliar; a constituição e distribuição dos tecidos foliares; a presença de canais secretores; e a distribuição dos tecidos no rizoma e raiz.

As características acima apresentadas estão relacionadas, em parte, com ambientes xerofíticos, onde a presença de água e nutrientes é escassa, como sucede em terrenos arenosos onde esta espécie é encontrada, sendo necessário o desenvolvimento de estruturas que permitem a economia e/ou o armazenamento destes elementos nos períodos secos.

Outra característica que merece menção é a eventual submersão dos indivíduos em períodos curtos de cheia (no caso de populações localizadas na planície de inundação do Alto rio Paraná). A ocorrência de canais de ar em seu sistema radical poderia ser uma estratégia para a sua sobrevivência em condições de anoxia. No entanto, são necessários maiores estudos de ecofisiologia, a fim de se comprovar esta possível tolerância.

\section{BIBLIOGRAFIA}

Andrighetti-Fröhner, C. R. et al. Antiviral evaluation of plants from Brazilian Atlantic Tropical Forest. Fitoterapia, v. 76, p. 374-378, 2005.

Aoyama, E. M., Sajo, M. G. Estrutura foliar de Aechmea Ruiz \& Pav. subgênero Lamprococcus (Beer) Baker e espécies relacionadas (Bromeliaceae). Rev. Bras. Bot., São Paulo, v. 26, n. 4, p. 461-473, 2003.

Benzing, D. H. Vascular epiphytes, general biology and related biota. Cambridge: Cambridge University Press, 1990.

Braga, M. M. N. Anatomia foliar de Bromeliaceae da Campina. Acta Amazonica, Manaus, v. 7 (supl.), n. 3, p. 1-74, 1977.
Canela, M. B. F., Sazima, M. The pollination of Bromelia antiacantha (Bromeliaceae) in Southeastern Brazil: Ornithophilous versus melittophilous features. Plant Biology, Stuttgart, v. 7, n. 4, p. 411-416, 2005. Cogliatti-Carvalho, L., Freitas, A. F. N., Rocha, C. F. D., Sluys, M. Variação na estrutura e na composição de Bromeliaceae em cinco zonas de restinga no Parque Nacional da Restinga de Jurubatiba, Macaé, RJ. Rev. Bras. Bot., São Paulo, v. 24, n. 1, p. 1-9, 2001.

Dettke, G. A., Milaneze-Gutierre, M. A. Germinação de Bromelia antiacantha Bertoloni (Bromelioideae Bromeliaceae): influência da estocagem, fotoperíodo e temperatura. In: Resumos da I Mostra de trabalhos científicos de graduação e pós-graduação em Agronomia. Maringá, 2004.

Johansen, D. A. Plant microtechnique. New York: Mcgraw-Hill, 1940. 523p.

Kraus, J., Arduim, M. Manual básico de método em morfologia vegetal. Seropédica: EDUR, 1997. 198p.

Meira, M. S. Distribuição espacial e estrutura de populações de bromeliáceas terrestres em um mosaico de floresta e campo. Porto Alegre: UFGRS, 1997. 96f. Dissertação (Mestrado).

Pita, P. B., Menezes, N. L. Anatomia da raiz de espécies de Dyckia Schult. f. e Encholirium Mart. ex Schult. \& Schult. f. (Bromeliaceae, Pitcairnioideae) da Serra do Cipó (Minas Gerais, Brasil), com especial referência ao velame. Rev. Bras. Bot., São Paulo, v. 25, n. 1, p. 25-34, 2002.

Proença, S. L., Sajo, M. G. Estrutura foliar de espécies de Aechmea Ruiz \& Pav. (Bromeliaceae) do Estado de São Paulo, Brasil. Acta Bot. Bras., Porto Alegre, v. 18, n. 2, p. 319-331, 2004.

Reitz, R.. Bromeliáceas e a malária-bromélia endêmica. In: Flora Ilustrada Catarinense (R. Reitz, ed.), Herbário Barbosa Rodrigues, Itajaí. 1983.

Scatena, V. L., Segecin, S. Anatomia foliar de Tillandsia L. (Bromeliaceae) dos Campos Gerais, Paraná, Brasil. Rev. Bras. Bot., São Paulo, v. 28, n. 3, p. 635-649, 2005.

Segecin, S., Scatena, V. L. Morfoanatomia de rizomas e raízes de Tillandsia $\mathrm{L}$. (Bromeliaceae) dos Campos Gerais, PR, Brasil. Acta Bot. Bras., Porto Alegre, v. 18, n. 2, p. 253-260, 2004.

Smith, L. B., Downs, R. J. Bromelioideae (Bromeliaceae). Flora Neotropica Monographies, New York, v. 14, p.1604-1724, 1979. 
Souza, G. M., Estelita, M. E. M., Wanderley, M. G. L. Anatomia foliar de espécies brasileiras de Aechmea subg. Chevaliera (Gaudich. ex Beer) Baker, Bromelioideae-Bromeliaceae. Rev. Bras. Bot., São Paulo, v. 28, n. 3, p. 603-613, 2005.

Souza, V. C., Lorenzi, H. Botânica Sistemática: guia ilustrado para identificação das famílias de Angiospermas da flora brasileira, baseado no AGP II. Nova Odessa, São Paulo: Instituto Plantarum. 2005.

Strehl, T. Forma, distribuição e flexibilidade dos tricomas foliares usados na filogenia de Bromeliaceae. Iheringia, Série Botânica, Porto Alegre, v. 31, p. 105-119, 1983.

Tomlinson, P. B. Commelinales-Zingiberales. In: Anatomy of the Monocotyledons (R.C. Metcalfe, ed.). Oxford: Clarendon Press, 1969. 1449 p. 